\title{
Effect of Cutting Height and Stage of Development on Lucerne Quality in the Po Plain
}

\author{
Giorgio Borreani ${ }^{* 1}$, Miriam Odoardi ${ }^{2}$, Amedeo Reyneri $^{1}$, Ernesto Tabacco ${ }^{1}$ \\ ${ }^{1}$ Dipartimento di Agronomia, Selvicoltura e Gestione del Territorio \\ Via L. da Vinci 44, 10095 Grugliasco (To), Italy \\ ${ }^{2}$ Istituto Sperimentale per le Colture Foraggere - C.R.A., Lodi, Italy
}

Received: 30 March 2004. Accepted: 10 November 2004

\begin{abstract}
To improve pre-harvest forage quality of lucerne an increase of the cutting height was studied under two high quality cutting schedules in a two year experiment. Two different harvest schedules (VB, first cut at late vegetative and following cuts at bud stage; VF, first cut at late vegetative and following cuts at early flowering) and two cutting height (4 and $14 \mathrm{~cm}$ ) were compared to evaluate dry matter (DM) yield, morphological stage of development, crude protein (CP), NDF, ADL, and enzymatic organic matter digestibility (OMD). The stratified quality was analysed in six canopy segments for a summer cut. Increasing the cutting height improved the protein and digestibility contents in both schedules without compromising the stand persistence. In the VB schedule the increase in the cutting height resulted in an NDF that was lower than $370 \mathrm{~g} \mathrm{~kg}^{-1} \mathrm{DM}$, while the OMD were always higher than $700 \mathrm{~g} \mathrm{~kg}^{-1} \mathrm{OM}_{\text {, }}$ both considered as threshold values for quality purposes. The OMD of the bottom parts of stem remained almost constant till $22 \mathrm{~cm}$ with values of 470 and $400 \mathrm{~g} \mathrm{~kg}^{-1} \mathrm{OM}$ for VB and VF, respectively. Leaves showed a constant quality with a CP content of $318 \mathrm{~g} \mathrm{~kg}^{-1} \mathrm{DM}$ and OMD of $769 \mathrm{~g} \mathrm{~kg}^{-1} \mathrm{OM}$. The increase in the cutting height leads to relevant improvement in the forage quality when performed at vegetative and early bud stages, while on more mature forages the increase in the height of cut proved to be a valuable method to increase forage quality only when performed over $20 \mathrm{~cm}$.
\end{abstract}

Key-words: cutting height, organic matter digestibility, Medicago sativa L., NDF, stratified forage quality.

\section{Introduction}

Home-grown lucerne (Medicago sativa L.), conserved as silage or hay, represents the most reliable source of high quality forage and can contribute in reducing costs of ruminant production. In order to satisfy the nutrient requirements of high performing dairy cows, forages should be characterised by high OMD (> $680 \mathrm{~g}$ $\mathrm{kg}^{-1} \mathrm{OM}$ ) and NDF lower or equal to $370 \mathrm{~g} \mathrm{~kg}^{-1}$ DM (Broderick, 1995; Nelson and Satter, 1992). This means that the pre-harvesting quality of forage had to be better than the previously stated values, because of the unavoidable harvesting and conservation losses (Demarquilly, 1987). It is widely recognised that the quality of lucerne decreases as the crop grows and matures (Nelson and Moser, 1994). The two major factors contributing to the low quality of ma- ture legumes are primarly the decrease in the leaf to stem ratio and the increase in the cell-wall concentration and lignification which is much faster in stems than in leaves (Marten et al., 1988). In legumes where stems are structural organs and leaves metabolic organs, the quality of leaves is almost constant over the growth cycle (Van Soest, 1994). Furthermore, stem segments are not uniform in digestibility and crude protein content with a lower quality in the bottom part (Buxton et al., 1985). Buxton and Casler (1993) observed that the quality of the forages decreases rapidly with the increase in the stem weight; the basal portion, in particular, is characterised by higher level of collenchyma cells and lignin which are only marginally digestible.

Since most of the lucerne protein $(70 \%$ of total plant) is located in the leaves, and most of the leaves are found in the upper parts of the

\footnotetext{
* Corresponding Author: Tel.: +39 011 6798783; Fax: +39 011 6708798. E-mail address: giorgio.borreani@unito.it
} 
plant canopy, Downs and Taylor (1989) propose an approach to improve forage quality by harvesting the top part of the plants separately. However, in order to determine the cutting height, it is necessary to analyse and quantify the average protein content and digestibility of the plant above or below the cut. Ogden and Kehr (1965) found that the top half of first cut lucerne contained $62 \%$ of the total protein and $39 \%$ of the crude fibre content. Nevertheless, an increase of the cutting height leads to a reduction of the herbage yield (Gervais and Girard, 1987).

Therefore, it is necessary to determine the maximum level to raise the cutting height without compromising the DM yield, profitability and persistence of the lucerne stand.

The objectives of this study were to evaluate the practical applicability and the possibility of further improving the pre-harvesting forage quality of lucerne by increasing the cutting height under two cutting schedules without influencing stand persistence.

\section{Materials and methods}

\subsection{Description of the site and experimental treat- ments}

The research was carried out over the 1996-1997 period in the Western Po Valley near Torino (44 ${ }^{\circ}$ $50^{\prime} \mathrm{N}, 7^{\circ} 40^{\prime} \mathrm{E}$, altitude $232 \mathrm{~m}$ a.s.l., annual mean temperature $11.5^{\circ} \mathrm{C}$, and annual average rainfall $747 \mathrm{~mm}$ ) on recent alluvium soil (Typic Udifluvents; USDA, 1997) with a sandy-loam texture and $\mathrm{pH}$ (in water) of 7.6. The soil sand, silt, and clay contents were 480, 430, and $90 \mathrm{~g} \mathrm{~kg}^{-1}$, respectively, at 0 - to $30-\mathrm{cm}$ depth. Organic $\mathrm{C}$ was $11.5 \mathrm{~g} \mathrm{~kg}^{-1}$ and organic $\mathrm{N}$ was $1.39 \mathrm{~g} \mathrm{~kg}^{-1}$. Stands of lucerne cv. Equipe were sown on 4 April 1996 , at $35 \mathrm{~kg} \mathrm{ha}^{-1}$ of pure live seed, and $10 \mathrm{~cm}$ row-spaced. All the plots were fertilised prior to sowing with $100 \mathrm{~kg} \mathrm{P}_{2} \mathrm{O}_{5} \mathrm{ha}^{-1}$ and $150 \mathrm{~kg} \mathrm{~K}_{2} \mathrm{O}$ ha $^{-1}$. No fertiliser or herbicide were applied after sowing. On 16 May 1996, a pre-cut was made to control weed development; no sampling was performed on this cut. Temperature and rainfall data were collected from a weather station that was $60 \mathrm{~m}$ from the experiment site.

Two heights of cut, 4 and $14 \mathrm{~cm}$, defined as standard and high, respectively, were managed under two cutting schedules:

- VB, first cut at late vegetative with crop height of $50-60 \mathrm{~cm}$, and following cuts at early bud stage;

- VF, first cut at late vegetative as VB, and following cuts at early flowering.

Cuttings were made according to the phenological stage utilising the system proposed by Kalu and Fick (1981). Dates of cutting are reported in Table 1.

Treatments were assigned to experimental units using a randomised complete block design. Each treatment had three replications. The total plot size, including pathways, was $20 \mathrm{~m}^{2}$. Samples for yield and quality were performed at each sampling time with a Haldrup forage plot harvester (modified to obtain the different cutting heights) on subplots of $12 \mathrm{~m}^{2}$ to avoid border effects between two neighbouring plots cut at different times. Plants were dug and counted from a random meter squared area of each plot in late October 1997 to determine the stand persistence.

The quality in canopy segments was evaluated in 1997 on the second regrowth of VB and VF. Approximately $1 \mathrm{~kg}$ of herbage was collected by hand clipping at ground level and taken to the laboratory for separation into six layers on three replications. The layers were: 0-4, 4-8, 8-14, 14-22, 22-40 and over $40 \mathrm{~cm}$. Three sub-samples for each fraction were separated into stems and leaves.

\subsection{Analytical procedures}

Forage samples were taken from each plot to determine the dry matter content at $90^{\circ} \mathrm{C}$, and

Table 1. Cutting date in the two experimental years for the two cutting stages.

\begin{tabular}{|c|c|c|c|c|c|c|c|c|c|c|c|c|}
\hline \multirow[t]{2}{*}{ Schedule } & \multicolumn{5}{|c|}{1996} & \multicolumn{7}{|c|}{1997} \\
\hline & $\dagger 1^{\text {st }}$ & $2^{\text {nd }}$ & $3^{\text {rd }}$ & $4^{\text {th }}$ & $5^{\text {th }}$ & $1^{\text {st }}$ & $2^{\text {nd }}$ & $3^{\text {rd }}$ & $4^{\text {th }}$ & $5^{\text {th }}$ & $6^{\text {th }}$ & $7^{\text {th }}$ \\
\hline \multirow[t]{2}{*}{ VB } & 15 & 12 & 9 & 7 & 29 & 22 & 21 & 18 & 23 & 11 & 18 & 31 \\
\hline & May & June & July & Aug. & Sept. & April & May & June & July & Aug. & Sept. & Oct. \\
\hline \multirow[t]{2}{*}{ VF } & 15 & 25 & 30 & 5 & 29 & 22 & 4 & 26 & 28 & 29 & 4 & \\
\hline & May & June & July & Sept. & Oct. & April & June & June & July & Aug. & Oct. & \\
\hline
\end{tabular}

$\dagger$ The first cut was made to control weed development and no sampling was performed. 
Table 2. Monthly and annual mean temperatures and cumulated rainfall for the studied period and the means for 25 years.

\begin{tabular}{|c|c|c|c|c|c|c|}
\hline \multirow[t]{2}{*}{ Month } & \multicolumn{3}{|c|}{ Temperature $\left({ }^{\circ} \mathrm{C}\right)$} & \multicolumn{3}{|c|}{ Rainfall (mm) } \\
\hline & 1996 & 1997 & $\begin{array}{c}\text { mean } \\
1976-1999\end{array}$ & 1996 & 1997 & $\begin{array}{c}\text { mean } \\
1976-1999\end{array}$ \\
\hline January & 2.3 & 1.0 & 0.6 & 105 & 47 & 35 \\
\hline February & 2.1 & 5.6 & 3.3 & 35 & 0 & 33 \\
\hline March & 6.6 & 10.1 & 7.6 & 27 & 1 & 53 \\
\hline April & 11.8 & 11.3 & 10.8 & 81 & 12 & 99 \\
\hline May & 16.2 & 16.9 & 15.9 & 95 & 19 & 108 \\
\hline June & 20.4 & 19.3 & 19.5 & 60 & 253 & 76 \\
\hline July & 20.9 & 21.2 & 22.0 & 33 & 39 & 36 \\
\hline August & 20.8 & 22.2 & 21.3 & 108 & 40 & 65 \\
\hline September & 14.5 & 19.2 & 17.3 & 75 & 50 & 66 \\
\hline October & 12.0 & 12.6 & 12.1 & 136 & 3 & 94 \\
\hline November & 7.0 & 6.2 & 5.6 & 79 & 45 & 53 \\
\hline December & 3.0 & 2.9 & 1.7 & 129 & 21 & 29 \\
\hline Annual & 11.6 & 12.4 & 11.5 & 963 & 530 & 747 \\
\hline
\end{tabular}

the morphological stage, following the mean stage by weight (MSW) method proposed by Kalu and Fick (1981).

Samples for qualitative analyses were dried in a forced-draft oven to constant weight at $65^{\circ}$ $\mathrm{C}$, air equilibrated, weighed, ground in a Cyclotec mill (Foss Tecator, Hoganas, Sweden) to pass a $1 \mathrm{~mm}$ screen.

The dried samples were analysed for total nitrogen (TN), by dry combustion according to the Dumas method (Kirsten, 1983) using a NA 1500 elemental analyser (CE Instruments, Milan, Italy), and crude protein (CP) calculated as $\mathrm{TN} \times 6.25$. Neutral-detergent fibre $(\mathrm{NDF})$ and acid detergent lignin (ADL) were determined according to Van Soest et al. (1991). Enzymatic organic matter digestibility (OMD) was carried out as described by Aufrère (1982).

\subsection{Statistical analysis}

DM yield and chemical compositional data, within each cut, were analysed for statistical significance via analysis of variance, with significance reported at 0.05 probability level using the general linear model of the Statistical Package for Social Science (Norusis, 1998). When calculated values for $F$ were significant, the RyanEinot-Gabriel-Welsch range test (Hochberg and Tamhane, 1987) was used to interpret significant differences among the means.

\section{Results and discussion}

The weather conditions were characterised by a cool spring and rainy season in 1996 (total rain- fall $963 \mathrm{~mm}$ ) and an early spring and warm September in 1997 with lower total rainfall (530 $\mathrm{mm}$ ) (Table 2). No frost damage was recorded during winter over the years. No irrigation was supplied, due to soil reserves and good rain distribution.

3.1 Dry matter yield, quality and persistence of lucerne harvested at two cutting heights

The individual and total harvest DM yield for the two cutting heights and schedules are reported in Table 3. Four cuts were performed in 1996 for each treatment, while the longer growing period in 1997, due to the early spring, allowed 7 and 6 cuts to be made for the VB and VF, respectively. In both years, the standard VB schedule yielded lower than the standard VF schedule; the difference of DM yield was $-20 \%$ in 1996 and $-17 \%$ in 1997. The reduction of total annual DM yield due to the increase of the cutting height was of $1.0 \mathrm{t}$ ha $^{-1}$ (9.7 vs. 8.7$)$ and $1.2 \mathrm{t} \mathrm{ha}^{-1}$ (15.0 vs. 13.8$)$ for the VB schedule, whereas for VF it was of $0.5 \mathrm{t}$ ha $^{-1}$ (12.2 vs. 11.7$)$ and 3.7 t ha $^{-1}$ (18.1 vs. 14.4$)$ for 1996 and 1997, respectively.

The digestibility values of each cut for the two cutting heights and schedules are reported in Table 4. An increase in OMD was observed with the more frequent cutting schedule (VB), as highlighted in the same environment by Tabacco et al. (2002). For the VB schedule, the higher cutting height increased the mean values of OMD by about 18 and $38 \mathrm{~g} \mathrm{~kg}^{-1} \mathrm{OM}$ in 1996 and 1997, respectively. Similar results were achieved for VF schedule with mean values of 19 and $31 \mathrm{~g} \mathrm{~kg}^{-1} \mathrm{OM}$ for the two years. 
Table 3. Individual cutting and total annual yield ( $\left.\mathrm{DM} \mathrm{ha}^{-1}\right)$ in the two experimental years. TDM, total annual dry matter yield; VB, first cut at late vegetative and following cuts at bud stage; VF, first cut at late vegetative and following cuts at early flowering; NS, not significant; $* P<0.05 ; * * P<0.01$; *** $P<0.001$.

\begin{tabular}{|c|c|c|c|c|c|c|c|c|c|c|c|c|c|c|}
\hline \multirow[t]{2}{*}{ Schedule } & \multirow{2}{*}{$\begin{array}{l}\text { Cutting } \\
\text { height }\end{array}$} & \multicolumn{5}{|c|}{1996} & \multicolumn{8}{|c|}{1997} \\
\hline & & $2^{\text {nd } \phi}$ & $3^{\text {rd }}$ & $4^{\text {th }}$ & $5^{\text {th }}$ & TDM & $1^{\text {st }}$ & $2^{\text {nd }}$ & $3^{\text {rd }}$ & $4^{\text {th }}$ & $5^{\text {th }}$ & $6^{\text {th }}$ & $7^{\text {th }}$ & TDM \\
\hline \multirow[t]{2}{*}{$\mathrm{VB}$} & standard & 3.1 & 2.5 & 2.1 & 2.0 & 9.7 & 4.4 & 2.1 & 2.1 & 2.6 & 1.1 & 1.5 & 1.2 & 15.0 \\
\hline & high & 2.3 & 2.6 & 2.0 & 1.8 & 8.7 & 3.6 & 1.9 & 2.0 & 2.4 & 1.3 & 1.5 & 1.1 & 13.8 \\
\hline \multirow[t]{2}{*}{ VF } & standard & 4.4 & 3.7 & 2.7 & 1.4 & 12.2 & 4.5 & 4.3 & 2.1 & 3.2 & 2.3 & 1.7 & & 18.1 \\
\hline & high & 4.4 & 3.6 & 2.6 & 1.1 & 11.7 & 3.1 & 3.3 & 1.7 & 2.8 & 2.1 & 1.5 & & 14.4 \\
\hline LSD & & 0.2 & 0.2 & 0.3 & 0.1 & 0.3 & 0.8 & 0.4 & 0.4 & 0.8 & 0.4 & 0.4 & - & 0.8 \\
\hline Schedule & & $* * *$ & $* * *$ & $* * *$ & $* * *$ & $* * *$ & NS & $* * *$ & NS & NS & $* * *$ & NS & - & $* * *$ \\
\hline Cut height & & $* * *$ & NS & NS & $* * *$ & $* * *$ & $* *$ & $* * *$ & NS & NS & NS & NS & NS & $* * *$ \\
\hline Schedule $\times$ & x cut height & $* * *$ & NS & NS & NS & * & NS & $*$ & NS & NS & NS & NS & - & $*$ \\
\hline
\end{tabular}

$\dagger$ The first cut was made to control weed development and no sampling was performed.

Table 4. Organic matter digestibility $\left(\mathrm{g} \mathrm{kg}^{-1} \mathrm{OM}\right)$ in the two years. VB, first cut at late vegetative and following cuts at bud stage; VF, first cut at late vegetative and following cuts at early flowering; NS, not significant; $* P<0.05 ; * * P<0.01$; $* * * P<0.001$.

\begin{tabular}{|c|c|c|c|c|c|c|c|c|c|c|c|c|}
\hline \multirow[t]{2}{*}{ Schedule } & \multirow{2}{*}{$\begin{array}{l}\text { Cutting } \\
\text { height }\end{array}$} & \multicolumn{4}{|c|}{1996} & \multicolumn{7}{|c|}{1997} \\
\hline & & $2^{\text {nd }} \dagger$ & $3^{\text {rd }}$ & $4^{\text {th }}$ & $5^{\text {th }}$ & $1^{\text {st }}$ & $2^{\text {nd }}$ & $3^{\text {rd }}$ & $4^{\text {th }}$ & $5^{\text {th }}$ & $6^{\text {th }}$ & $7^{\text {th }}$ \\
\hline \multirow[t]{2}{*}{ VB } & standard & 725 & 712 & 675 & 627 & 757 & 724 & 655 & 652 & 684 & 659 & 746 \\
\hline & high & 742 & 736 & 699 & 632 & 815 & 756 & 674 & 702 & 714 & 687 & 796 \\
\hline \multirow[t]{2}{*}{ VF } & standard & 646 & 607 & 657 & 598 & 759 & 679 & 676 & 668 & 655 & 631 & \\
\hline & high & 682 & 636 & 659 & 607 & 810 & 698 & 728 & 684 & 660 & 672 & \\
\hline LSD & & 45 & 36 & 38 & 27 & 34 & 36 & 42 & 30 & 23 & 27 & \\
\hline Schedule & & $* * *$ & $* * *$ & $*$ & $*$ & NS & $* * *$ & $*$ & NS & $* * *$ & $*$ & - \\
\hline Cut height & & $*$ & $*$ & NS & NS & $* * *$ & $*$ & $*$ & $* *$ & $*$ & $* *$ & $* *$ \\
\hline Schedule $\times$ & It height & NS & NS & NS & NS & NS & NS & NS & NS & NS & NS & - \\
\hline
\end{tabular}

$†$ The first cut was made to contrast weed development and no sampling was performed.

Table 5. Crude protein, NDF and ADL ( $\mathrm{g} \mathrm{kg}^{-1} \mathrm{DM}$ ): average values of all cuts in 1996, values of the first cut and of the average of all the other following cuts in 1997. CP, crude protein; NDF, neutral detergent fibre; ADL, acid detergent lignin; $\mathrm{VB}$, first cut at late vegetative and following cuts at bud stage; VF, first cut at late vegetative and following cuts at early flowering; NS, not significant; $* P<0.05 ; * * P<0.01 ; * * * P<0.001$.

\begin{tabular}{|c|c|c|c|c|c|c|c|c|c|c|}
\hline \multirow[t]{2}{*}{ Schedule } & \multirow{2}{*}{$\begin{array}{l}\text { Cutting } \\
\text { height }\end{array}$} & \multicolumn{3}{|c|}{1996} & \multicolumn{5}{|c|}{1997} & \multirow[b]{2}{*}{$\begin{array}{c}\text { Other } \\
\text { cuts }\end{array}$} \\
\hline & & \multicolumn{3}{|c|}{ All other cuts } & $\begin{array}{c}\mathrm{CP} \\
1^{\text {st }} \text { cut }\end{array}$ & $\begin{array}{l}\text { Other } \\
\text { cuts }\end{array}$ & $\begin{array}{l}\mathrm{NDF} \\
1^{\text {st }} \mathrm{cut}\end{array}$ & $\begin{array}{l}\text { Other } \\
\text { cuts }\end{array}$ & $\begin{array}{l}\text { ADL } \\
1^{\text {st }} \text { cut }\end{array}$ & \\
\hline \multirow[t]{2}{*}{ VB } & standard & 204 & 381 & 70 & 215 & 210 & 301 & 400 & 51 & 68 \\
\hline & high & 213 & 369 & 65 & 228 & 221 & 276 & 358 & 53 & 62 \\
\hline \multirow[t]{2}{*}{$\mathrm{VF}$} & standard & 192 & 412 & 79 & 217 & 191 & 302 & 418 & 51 & 74 \\
\hline & high & 201 & 401 & 77 & 227 & 202 & 274 & 398 & 54 & 70 \\
\hline \multicolumn{2}{|l|}{ LSD } & 15 & 11 & 4 & 12 & 10 & 17 & 27 & 3 & 9 \\
\hline \multicolumn{2}{|l|}{ Schedule } & $*$ & $* * *$ & $* * *$ & NS & $* * *$ & NS & $* *$ & NS & $*$ \\
\hline \multicolumn{2}{|l|}{ Cut height } & NS & $* *$ & $*$ & $*$ & $* *$ & $* * *$ & $* *$ & $*$ & NS \\
\hline \multicolumn{2}{|c|}{ Schedule $\times$ cut height } & NS & NS & NS & NS & NS & NS & NS & NS & NS \\
\hline
\end{tabular}

The CP, NDF and ADL are reported in Table 5 , as the average values of all cuts in 1996, values of the first cut and of the average of all the other following cuts in 1997. The cutting schedule VB improved the quality in terms of $\mathrm{CP}$, NDF and ADL, except for the first cut in 1997 which is performed at the same late vegetative stage of development.

The higher cutting height significantly improved the quality parameters except for the $\mathrm{CP}$ content in 1996 and the ADL content in the summer cuts of 1997. The higher cutting height 
Table 6. Plant number at the end of the second year. VB, first cut at late vegetative and following cuts at bud stage; $\mathrm{VF}$, first cut at late vegetative and following cuts at early flowering; NS, not significant; $* P<0.05$.

\begin{tabular}{|c|c|c|}
\hline & \multicolumn{2}{|c|}{ Plant $\left(\mathrm{n}^{\circ} \mathrm{m}^{-2}\right)$} \\
\hline & VB & $\mathrm{VF}$ \\
\hline Cutting standard & 44 & 56 \\
\hline Cutting high & 58 & 61 \\
\hline LSD & \multicolumn{2}{|c|}{10} \\
\hline Schedule & \multicolumn{2}{|c|}{$*$} \\
\hline Cut height & \multicolumn{2}{|c|}{$*$} \\
\hline Schedule $\times$ cut height & \multicolumn{2}{|c|}{ NS } \\
\hline
\end{tabular}

in particular decreased the NDF content with a mean difference of about $27 \mathrm{~g} \mathrm{~kg}^{-1} \mathrm{DM}$. Values of NDF and ADL observed for the high VB schedule over the whole season can be considered to be of great interest for nutritional purposes when their quality can be successfully conserved till animal feeding (Mertens, 2000).

The VB schedule significantly reduced plant number at the end of the second year (Table 6). The higher cutting height in the more frequent cutting schedule resulted in a number of plants similar to those observed for the VF schedule. It is clearly demonstrated that frequent cutting schedules can influence carbohydrate root reserves and the vigour of lucerne stands (e.g. Gossen et al., 1994), while tall stubble furnishes additional energy for initial regrowth after cutting (Sheaffer et al., 1988). These results confirmed those obtained by Reyneri et al. (1995) in the same environment with a cutting height of 4 and $8 \mathrm{~cm}$. However, in environment with little risk of winter chilling damage, a number of about 40-50 plants per squared meter at the end of the second growth year is sufficient to ensure a good yield in the subsequent year (Sheaffer et al., 1988).

\subsection{Quality of stem segments and leaves}

The digestibility of the stems resulted in a great stratification from the bottom to the top parts in both schedules (Table 7). In the bottom parts, digestibility resulted to be very low and constant till $22 \mathrm{~cm}$, with values of around 470 and $400 \mathrm{~g}$ $\mathrm{kg}^{-1} \mathrm{OM}$ for VB and VF, respectively. In the upper zone, it reached a mean value of $564 \mathrm{~g} \mathrm{~kg}^{-1}$ $\mathrm{OM}$ in both schedules. The $\mathrm{CP}$ content varied with the increasing height of cut, from 80 to 151 $\mathrm{g} \mathrm{kg}^{-1} \mathrm{DM}$ and from 80 to $134 \mathrm{~g} \mathrm{~kg}^{-1} \mathrm{DM}$ for the VB and VF, respectively. Downs and Taylor
(1989) noted that the protein quality of stemmy portions improves considerably in the top one half of the plant. The $\mathrm{CP}$ and OMD of the leaf were almost constant with a mean value of 318 $\pm 3 \mathrm{~g} \mathrm{~kg}^{-1} \mathrm{DM}$ and $769 \pm 27 \mathrm{~g} \mathrm{~kg}^{-1} \mathrm{OM}$, respectively (data not shown in table). These values are in agreement with the statements of Mowat et al. (1965) and Kalu and Fick (1983) which found a relative constant value for $\mathrm{CP}$ and $\mathrm{OMD}$ of lucerne leaf over the whole growth cycle.

\subsection{Forage quality of stratified canopy}

The DM yield and quality of forage harvested at different cutting heights in the second regrowth of 1997 is shown in Figures 1 and 2. A linear reduction in DM yield was observed till $22 \mathrm{~cm}$ of cutting height for both schedules. Comparing the standard cutting height $(4 \mathrm{~cm})$ with the $22 \mathrm{~cm}$ height, a yield reduction of $29 \%$ and $21 \%$ was observed for VB and VF, respectively, whereas cutting at $40 \mathrm{~cm}$ reduced the yield by $68 \%$ and $63 \%$ for the two cutting schedules (Figure 1a). The yield harvested with cut at 40 $\mathrm{cm}$ was similar to the yield of the whole leaves.

The increase in OMD, compared to the standard cutting height, was of 38 and $31 \mathrm{~g} \mathrm{~kg}^{-1} \mathrm{OM}$ for $22 \mathrm{~cm}$ cutting height and of 96 and $98 \mathrm{~g} \mathrm{~kg}^{-1}$ $\mathrm{OM}$ for $40 \mathrm{~cm}$ in the two schedules, respectively (Figure 1b). When the cutting height increased from 4 to $40 \mathrm{~cm}$, the $\mathrm{CP}$ content of the whole plant ranged from 215 to $279 \mathrm{~g} \mathrm{~kg}^{-1} \mathrm{DM}$ for VB and from 196 to $267 \mathrm{~g} \mathrm{~kg}^{-1} \mathrm{DM}$ for VF (Figure 2a). At the same time the NDF content decreased from 394 to $258 \mathrm{~g} \mathrm{~kg}^{-1} \mathrm{DM}$ and from 413 to $270 \mathrm{~g} \mathrm{~kg}^{-1} \mathrm{DM}$ for $\mathrm{VB}$ and $\mathrm{VF}$, respectively

Table 7. Organic matter digestibility (OMD) and crude protein (CP) of stem segments of the second regrowth of 1997 for the two cutting schedules. VB, first cut at late vegetative and following cuts at bud stage; $\mathrm{VF}$, first cut at late vegetative and following cuts at early flowering; NS, not significant; **P $<0.01 ; * * * P<0.001$.

\begin{tabular}{|c|c|c|c|c|}
\hline \multirow{2}{*}{$\begin{array}{l}\text { Stem } \\
\text { segment }(\mathrm{cm})\end{array}$} & \multicolumn{2}{|c|}{$\mathrm{OMD}\left(\mathrm{g} \mathrm{kg}^{-1} \mathrm{OM}\right)$} & \multicolumn{2}{|c|}{$\mathrm{CP}\left(\mathrm{g} \mathrm{kg}^{-1} \mathrm{DM}\right)$} \\
\hline & VB & VF & VB & VF \\
\hline $0-4$ & 446 & 398 & 80 & 80 \\
\hline $4-8$ & 467 & 401 & 93 & 75 \\
\hline $8-14$ & 472 & 409 & 107 & 75 \\
\hline $14-22$ & 482 & 428 & 106 & 86 \\
\hline $22-40$ & 514 & 456 & 128 & 104 \\
\hline$>40$ & 564 & 563 & 151 & 134 \\
\hline LSD & \multicolumn{2}{|c|}{21} & \multicolumn{2}{|c|}{11} \\
\hline Schedule & \multicolumn{2}{|c|}{$* * *$} & \multicolumn{2}{|c|}{$* * *$} \\
\hline Cut height & \multicolumn{2}{|c|}{$* * *$} & \multicolumn{2}{|c|}{$* * *$} \\
\hline Schedule $\mathrm{x}$ cut height & \multicolumn{2}{|c|}{$* * *$} & \multicolumn{2}{|c|}{$* *$} \\
\hline
\end{tabular}




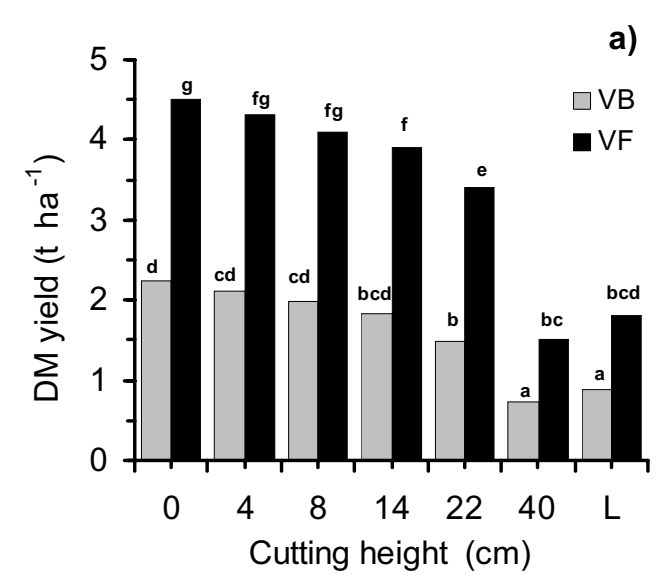

b)

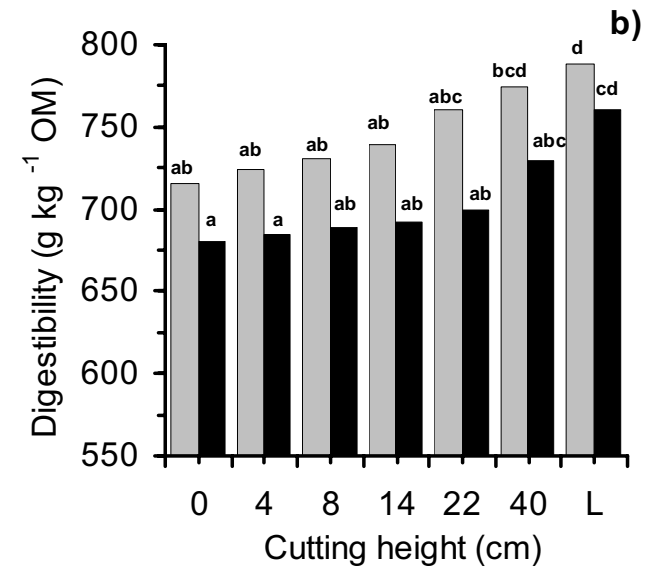

Figure 1. DM yield (a) and digestibility (b) in the second regrowth of 1997 at different cutting height. L, leaf.

(Figure 2b). Downs and Taylor (1989) found that $\mathrm{CP}$ and fibre content of the plant cut at two stages of maturity (early- and mid-flowering) increased faster, with increasing height of cut, in the more mature crop and reached the same values of the younger herbage at a cutting height of $50 \%$ of the total plant height (around 35-40 cm).

The same authors (Downs and Taylor, 1989) stated that a cutting height higher than $20 \mathrm{~cm}$ at farm scale level requires that the lower portions should be subsequently cut and windrowed for field curing, or green chopped thus increasing harvesting costs and traffic damage to the crop.

The present results have shown that forage pre-harvesting quality can be increased by raising the cutting height, but it should also be considered that following mechanical harvest operations and conservation method can influence the final feeding quality.

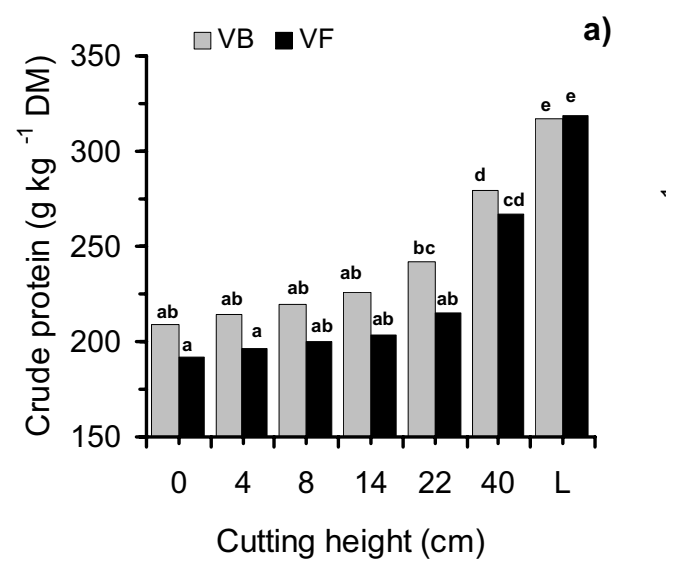

b)

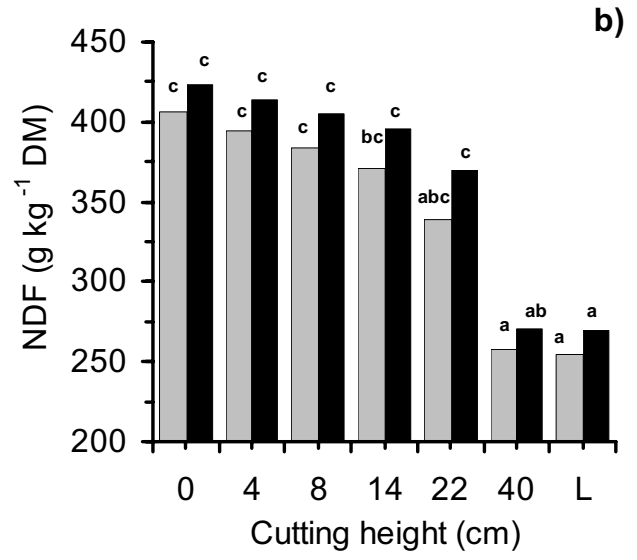

Figure 2. Crude protein (a) and NDF (b) content in the second regrowth of 1997 at different cutting height. L, leaf.

\section{Conclusions}

Increasing the cutting height of lucerne from 4 to $14 \mathrm{~cm}$ produces a forage with considerably higher protein and digestibility.

Furthermore higher cutting resulted in a positive influence on the stand persistence. Increase in the cutting height leads to relevant improvement in the forage quality when performed at vegetative and early bud stages, resulting in forage with lower NDF than $370 \mathrm{~g} \mathrm{~kg}^{-1} \mathrm{DM}$, higher CP than $210 \mathrm{~g} \mathrm{~kg}^{-1} \mathrm{DM}$ and always higher OMD than $700 \mathrm{~g} \mathrm{~kg}^{-1} \mathrm{OM}$ for all the harvests. When cutting was performed on more mature forages, the increase in the height of cut proved to be a valuable method to increase forage quality only with a higher cutting height than $20 \mathrm{~cm}$. This cutting height cannot be applied in the field without creating problems for the subsequent cuts due to the presence of a low quality stubble. Obviously, the cutting height can be raised 
to $15 \mathrm{~cm}$ only when stands are not lodged. Therefore a higher cutting height is applicable in the field when harvesting is performed at early growth stages, especially in the first growth.

Further research is necessary to verify the possibility of harvesting and conserving this high pre-harvest quality under conventional harvesting methods at a farm scale level.

\section{Acknowledgements}

The authors wish to thank Mario Gilardi (Dipartimento di Agronomia, Selvicoltura e Gestione del territorio) for the technical assistance in the field, Barbara Pintus and Agata Ursino (Istituto Sperimentale Colture Foraggere) for the chemical analyses.

This work was funded by the Ministero dell'Istruzione, dell'Università e della Ricerca (MIUR). The work is attributable in equal parts to the authors.

\section{References}

Aufrère J. 1982. Etude de la prevision de la digestibilité des fourrages par une methode enzymatique. Ann. Zootech., 31:111-130.

Broderick G.A. 1995. Performance of lactating dairy cows fed either alfalfa silage or alfalfa hay as the sole forage. J. Dairy Sci., 78:320-329.

Buxton D.R., Hornstein J.S., Wedin, W.F., Marten G.C. 1985. Forage quality in stratified canopies of alfalfa, birdsfoot trefoil, and red clover. Crop Sci., 25:273279.

Buxton D.R., Casler M.D. 1993. Environmental and genetic effects on cell wall composition and digestibility. In: Jung H.G., Buxton D.R., Hatfield R.D., Ralph J. (eds.): Forage cell wall structure and digestibility: 585-614. ASA Inc., Madison, WI.

Demarquilly D. 1987. Les fourrages secs: récolte, traitement, utilisation. Paris: INRA.

Downs H.W., Taylor R.K. 1989. Varying cutting height to produce high-protein, low fiber fractions from alfalfa. Trans. ASAE, 32:787-790.

Gervais P., Girard J.M. 1987. Influence de la hauteur et de la frequence des coupes sur le rendement, le peuplement, la composition chimique et les reserves nutritives de la luzerne. Can. J. Plant Sci., 67:735-746.

Gossen B.D., Horton P.R., Wright S.B.M., Duncan C.H. 1994. Field response of alfalfa to harvest frequency, cultivar, crown pathogens, and soil fertility: I. Survival and yield. Agron. J., 86:82-88.

Hochberg Y., Tamhane A.C. 1987. Multiple comparison procedures. John Wiley and Sons, NY.
Kalu B.A., Fick G.W. 1981. Quantifying morphological development on alfalfa for studies of herbage quality. Crop Sci., 21:267-271.

Kalu B.A., Fick G.W. 1983. Morphological stage of development as a predictor of alfalfa herbage quality. Crop Sci., 23:1167-1172.

Kirsten W.J. 1983. Rapid, automatic, high capacity Dumas determination of nitrogen. Microchem. J., 28:529547.

Marten G.C., Buxton D.R., Barnes R.F. 1988. Feeding value. In: Hanson A.A., Barnes D.K., Hill R.R. (eds.): Alfalfa and alfalfa improvement. 465-492. ASA Inc., Madinson, WI.

Mertens D.R. 2000. Physically effective NDF and its use in dairy rations explored. Feedstuff, 11-14.

Mowat D.N., Fulkerson R.S., Tossell W.E., Wich J.E. 1965. The in vitro digestibility and protein content of leaf and stem portions of forages. Can. J. Plant Sci., 45:321-331.

Nelson W.F., Satter L.D. 1992. Impact of alfalfa maturity and preservation method on milk production by cows in early lactation. J. Dairy Sci., 75:1562-1570.

Nelson C.J., Moser L.E. 1994. Plant factors affecting forage quality. In: Fahey G.C., Collins M., Mertens D.R., Moser L.E. (eds.): Forage quality, evaluation and utilization.115-154. ASA-CSSA-SSSA, Madison, WI.

Norusis M.J. 1998. Statistical Package for the Social Sciences. 8.0 Guide to data analysis. New Jersey, Prentice Hall.

Ogden R.L., Kehr W.B. 1965. Alfalfa management for dehydration. In: Proc. 9th Technical Alfalfa Conference, 36-74. USDA-ARS.

Reyneri A., Borreani G., Ciotti A. 1995. Effetto dell'epoca di esecuzione del primo taglio e dell'altezza di taglio su tre varietà di erba medica (Medicago sativa L.). Riv. Agron., 29:574-581.

Sheaffer C.C., Lacefield G.D., Marble V.L. 1988. Cutting schedules and stands. In: Hanson A.A., Barnes D.K., Hill R.R. (eds.): Alfalfa and alfalfa improvement, 411-438. ASA Inc., Madinson, WI.

Tabacco E., Borreani G., Odoardi M., Reyneri A. 2002. Effect of cutting frequency on dry matter yield and quality of lucerne (Medicago sativa L.) in the Po Valley. Ital. J. Agron., 6:27-33.

USDA 1997. Keys to soil taxonomy. 7th ed. Soil Survey Staff, USDA-SCS. Pocahontas Press, Pocahontas, VA.

Van Soest P.J., Robertson J.B., Lewis B.A. 1991. Methods for dietary fiber, neutral detergent fiber, and nonstarch polysaccharides in relation to animal nutrition. J. Dairy Sci., 74:3568-3597.

Van Soest P.J. 1994. Nutritional ecology of the ruminant. 2nd Edition. Cornell University Press, Ithaca, NY. 